\title{
INFLAMMATORY REACTION AND CAPILLARY LEAK SYNDROME RELATED TO CARDIOPULMONARY BYPASS IN NEONATES UNDERGOING CARDIAC OPERATIONS
}

Marie-Christine Seghaye, $\mathrm{MD}^{\mathrm{a}}$

Ralph G. Grabitz, MD ${ }^{\mathrm{a}}$

Jean Duchateau, $\mathbf{M D}^{\mathrm{b}}$

Sabine Busse ${ }^{a}$

Sabine Däbritz, $\mathrm{MD}^{\mathrm{c}}$

Dieter Koch, $\mathrm{MD}^{\mathrm{a}}$

Gerhard Alzen, $\mathrm{MD}^{\mathrm{d}}$

Helmut Hörnchen, $\mathrm{MD}^{\mathrm{e}}$

Bruno J. Messmer, $\mathrm{MD}^{\mathrm{c}}$

Götz von Bernuth, $\mathrm{MD}^{\mathrm{a}}$
We studied the inflammatory reaction related to cardiopulmonary bypass in 24 neonates (median age 6 days) undergoing the arterial switch operation for simple transposition of the great arteries, with respect to the development of postoperative capillary leak syndrome. Complement proteins, leukocyte count, tumor necrosis factor- $\alpha$, and histamine levels were determined before, during, and after cardiopulmonary bypass. Additionally, protein movement from the intravascular into the extravascular space during cardiopulmonary bypass was assessed by the measurement of plasma concentrations of proteins with molecular weights ranging from 21,200 to 718,000 . Capillary leak syndrome developed in 13 of the 24 neonates. Patients with capillary leak syndrome, as compared with those without, had preoperatively higher C5a levels (C5a, 3.0 $\pm 0.6 \mu \mathrm{g} / \mathrm{L}$ vs $0.9 \pm$ $0.2 \mu \mathrm{g} / \mathrm{L}$ ) (mean \pm standard error of the mean) $(p<0.05)$ and higher leukocyte counts (leukocytes, $17.9 \pm 2.1 \times 10^{3}$ cells $/ \mathrm{ml}$ versus $11.7 \pm 0.8 \times$ $10^{3}$ cells $\left./ \mathrm{ml}\right)(p<0.05)$, suggesting in these neonates a preoperative inflammatory state. Preoperative clinical and operative data were identical in both patient groups. Before cardiopulmonary bypass, serum protein concentrations were similar in all patients. Ten minutes after institution of cardiopulmonary bypass, protein concentrations fell to significantly lower values in patients with capillary leak syndrome than in those without: albumin $(19 \% \pm 1.5 \%$ vs $30 \% \pm 6 \%$ of the prebypass value, $p<0.05)$ immunoglobulin $\mathrm{G}(17 \% \pm 1.5 \%$ vs $29 \% \pm 5.5 \%, p<0.001)$, and $\alpha_{2}$-macroglobulin $(15 \% \pm 1.2 \%$ vs $25 \% \pm 4 \%, p<0.02)$. During cardiopulmonary bypass, albumin concentrations remained significantly lower in patients with capillary leak syndrome than in those without, whereas hematocrit values were similar in both groups. During cardiopulmonary bypass, patients with capillary leak syndrome also had lower concentrations of complement proteins $\mathrm{C} 3$ and $\mathrm{C} 4$ but not $\mathrm{C} 1$ inhibitor. $\mathrm{C} 3 \mathrm{~d} / \mathrm{C} 3 \mathrm{ratio}$ and C5a levels were similar in both patient groups. In contrast, histamine liberation during cardiopulmonary bypass was significantly more pronounced in patients with capillary leak syndrome than in those without $(725.2 \pm 396.7 \mathrm{pg} / \mathrm{ml}$ vs $-\mathbf{5 4 . 1} \pm \mathbf{5 8 . 4} \mathrm{pg} / \mathrm{ml}, p<\mathbf{0 . 0 5})$. Tumor necrosis factor- $\alpha$ levels after protamine administration were also significantly higher in patients with capillary leak syndrome $(38.1 \pm 10.0 \mathrm{pg} / \mathrm{ml}$ vs $15.3 \pm 3.4 \mathrm{pg} / \mathrm{ml}, p<0.05$ ). Leukocyte count during and after cardiopulmonary bypass was similar in both patient groups. This study demonstrates increased protein leakage as early as 10 minutes after initiation of
From the Departments of Pediatric Cardiology, ${ }^{a}$ Thoracic and Cardiovascular Surgery, ${ }^{\mathrm{c}}$ Diagnostic Radiology, ${ }^{\mathrm{d}}$ and Neona-

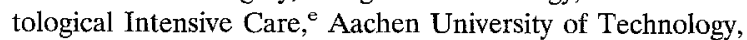
Aachen, Germany, and the Department of Immunology, ${ }^{b}$ University Hospitals Brugmann and St. Pierre, Free University Brussels, Brussels, Belgium.

Received for publication Dec. 14, 1995; revisions requested Jan. 29, 1996; revisions received Feb. 26, 1996; accepted for publication March 1, 1996.
Address for reprints: Marie-Christine Seghaye, MD, Department of Pediatric Cardiology, Aachen University of Technology, Pauwelsstrasse 30, D. 52057 Aachen, Germany.

J Thorac Cardiovasc Surg 1996;112:687-97

Copyright 1996 by Mosby-Year Book, Inc.

$0022-5223 / 96 \$ 5.00+0 \quad \mathbf{1 2 / 1 / 7 3 2 3 7}$ 
cardiopulmonary bypass in patients having clinical signs of postoperative capillary leak syndrome. Patients with capillary leak syndrome displayed more pronounced histamine liberation and tumor necrosis factor- $\alpha$ liberation than patients without capillary leak syndrome, suggesting a relationship between cardiopulmonary bypass-related inflammatory reaction and perioperative capillary damage. A preoperative inflammatory state in patients with capillary leak syndrome could have enhanced the inflammatory response to cardiopulmonary bypass. (J Thorac Cardiovasc Surg 1996; 112:687-97)

$0^{p}$ perations involving cardiopulmonary bypass (CPB) induce a complex systemic inflammatory reaction including synthesis and systemic release of inflammatory mediators. ${ }^{1-6} \mathrm{We}^{7}$ have previously shown that neonates display significant complement activation and leukocyte stimulation when undergoing cardiac operations.

Among the mediators liberated in the setting of CPB, complement anaphylatoxins, vasoactive amines such as histamine, and cytokines such as tumor necrosis factor- $\alpha(\mathrm{TNF}-\alpha)$ have the capability to increase microvascular permeability. 8,9

Increased microvascular permeability and changes in water balance hormones and control factors of endothelial integrity such as atrial natriuretic peptide ${ }^{10,11}$ promote interstitial protein-rich edema and water accumulation in the interstitial space. ${ }^{12,13}$ Neonates with normally facilitated fluid movements across the capillary membrane, and with rapid fluid shift from the intravascular into the interstitial space in case of fluid overload, ${ }^{14}$ are at particularly high risk for the development of generalized edema as a result of microvascular protein leakage during CPB. Indeed, younger age has been recognized among risk factors for rise in total body water accumulation after cardiac operations. ${ }^{15} \mathrm{De}-$ spite the relatively high prevalence of postoperative capillary leak syndrome (CLS) in neonates, data on the influence of risk factors including CPB-related inflammatory reaction are lacking. It was therefore the aim of our prospective study to analyze risk factors for postoperative CLS and to compare complement activation, leukocyte counts, TNF- $\alpha$ production, and histamine liberation before, during, and after CPB operations in neonates with and without postoperative development of CLS.

\section{Patients and methods}

Clinical

Patients. After approval by the Human Ethical Committee of the Aachen University of Technology and informed consent of the parents, 24 consecutive term neonates aged 2 to 23 days (median 6 days) were included in this prospective study. Inclusion criterion was a simple transposition of the great arteries suitable for the arterial switch operation. All patients received prostaglandin $\mathrm{E}_{1}$ infusion before the operation to maintain ductus arteriosus patency. Maternal-fetal infection or bacterial infection before the operation, neonatal asphyxia, and preoperative organ dysfunction were excluded in all cases. Cardiac catheterization for balloon atrial septostomy and angiocardiography was performed in 16 patients 1 to 18 days before the operation. Thirteen patients were treated by mechanical ventilation for 24 to 264 hours before the operation for respiratory insufficiency caused by prostaglandin $\mathrm{E}_{1}$.

Anesthesia and antibiotic regimen. Conventional general anesthesia was performed. Cefotiam hydrochloride (25 $\mathrm{mg} / \mathrm{kg}$ ) and dexamethasone $\left(3 \mathrm{mg} / \mathrm{m}^{2}\right.$ body surface area) given for prophylaxis of cerebral edema were administered before sternotomy.

$C P B$. The $C P B$ protocol included a roller pump, a disposable membrane oxygenator, and an arterial filter. Cooling and rewarming were carried out with a heat exchanger. The priming solution consisted of a crystalloid solution, mannitol ( $3 \mathrm{ml} / \mathrm{kg})$, and packed red cells to obtain a hematocrit value of the circulating volume of about $25 \%$. Heparinization was achieved with heparin sulfate ( $3 \mathrm{mg} / \mathrm{kg}$ ). Aprotinin was given intravenously $(10,000 \mathrm{IU} / \mathrm{kg})$ on induction of $\mathrm{CPB}$ and mixed in the priming solution $(10,000 \mathrm{IU} / \mathrm{kg})$. For vasodilation in the cooling and rewarming periods, all neonates received a continuous infusion of sodium nitroprusside $(0.5$ to 2.3 $\mu \mathrm{g} / \mathrm{kg}$ per minute, median $1 \mu \mathrm{g} / \mathrm{kg}$ per minute). Blood, fresh frozen plasma, and albumin were not substituted before the beginning of rewarming at the end of CPB.

CPB was instituted with a perfusion index of 2.7 $\mathrm{L} / \mathrm{min} \times \mathrm{m}^{2}$, which was maintained throughout the cooling phase. After deep hypothermia was reached (minimal nasopharyngeal temperature averaging $15^{\circ} \mathrm{C}$ ), aortic crossclamping was done, cardioplegia was induced by a single intraaortic injection of a $4^{\circ} \mathrm{C}$ cold Bretschneider solution $(30 \mathrm{ml} / \mathrm{kg})$, and complete circulatory arrest was instituted for not longer than 60 minutes. If necessary, the surgical procedure was continued under low-flow perfusion ( $25 \%$ of the calculated initial perfusion rate). Rewarming was achieved under full-flow conditions. The lungs of the neonates were reventilated when core temperature reached $30^{\circ} \mathrm{C}$. Neutralization of heparin was 
achieved with protamine sulfate in a 1:1 ratio. Epinephrine, dopamine, and sodium nitroprusside were systematically administered for weaning of the patients from CPB.

Postoperative care. Postoperative monitoring included continuous registration of heart rate and rhythm, arterial blood pressure, central venous pressure, and urine output. Target values for mean arterial blood pressure, central venous pressure, and urine output during the first 72 hours after the operation were about $45 \mathrm{~mm} \mathrm{Hg}, 5$ to 7 $\mathrm{mm} \mathrm{Hg}$, and more than $1.5 \mathrm{ml} / \mathrm{kg}$ per hour, respectively. Inotropic support, vasodilatory treatment, and diuretic treatment consisting of epinephrine, dopamine, sodium nitroprusside, and furosemide were adapted accordingly, as was volume substitution, which was carried out with fresh frozen plasma or 5\% human albumin. Fluid balance (fluid input including crystalloid and colloid solutions, fluid output including urine and drainage secretions) was assessed every 4 hours for the first 72 hours after the operation. Specific cardiologic examinations included electrocardiograms and echocardiograms, performed at least once a day, which allowed the evaluation of cardiac rhythm and function as assessed by the size of cardiac cavities and ventricular wall motion. Repeated sonograms of the chest and abdomen allowed diagnosis of pleural and intraabdominal effusions. Chest roentgenograms were carried out at the bedside under constant conditions (film-focus distance, $1 \mathrm{~m}$, patient in the supine position) at least once a day during the 3 first postoperative days.

So that tissue edema could be quantified, a radiologic index was established. The radiologic index was calculated as the ratio of the dimension of soft tissues measured at the height of the eighth rib to the diameter of the eighth rib measured at the midclavicular line, the latter serving as a reference being unaffected by edema and variations of thoracic geometry. Measurements were performed on the preoperative chest $x$-ray film, 1 hour after the operation, and on the first, second, and third postoperative days. Besides blood gas analysis and serum electrolytes, serum creatinine, aspartate aminotransferase, and creatine kinase were routinely measured during the first 3 days after the operation. The ratio of arterial oxygen tension (millimeters of mercury) to inspired oxygen fraction was used as an oxygenation parameter in patients receiving ventilatory assistance.

Definition of postoperative CLS. CLS was defined as the development of noncardiogenic generalized edema including pleural effusions or ascites (or both) and blood pressure instability necessitating volume substitution.

\section{Laboratory tests}

Collection of samples. Venous blood was collected before and after the operation. During CPB, blood was withdrawn from the arterial line of the circuit. For each sample time, $2.0 \mathrm{ml}$ of blood was taken in tubes containing ethylenediaminetetraacetic acid. The samples were immediately centrifuged for 3 minutes ( $3000 \mathrm{rpm})$ and the plasma was stored at $-70^{\circ} \mathrm{C}$ until analysis.

Plasma samples were collected before the operation, after heparin administration, 10 minutes after the onset of CPB, after complete circulatory arrest, 10 minutes after recirculation, after lung reventilation, at the end of the rewarming period, after protamine administration, and 4, 24,48 , and 72 hours after the end of CPB.
Complement fractions. $\mathrm{C} 3, \mathrm{C} 4$, and $\mathrm{C} 1$ inhibitor (molecular weight [MW] 190,000, 198,000, and 90,000, respectively) were determined by laser nephelometry ${ }^{16}$ with the immunoglobulin $\mathrm{G}$ fraction of a rabbit antihuman C3, C4, or $\mathrm{C} 1$ inhibitor antiserum with an automated procedure (Behring nephelometer analyzer, Behring Diagnostics, Hoechst, Belgium).

For C3d (MW 35,000) determination, the sample was incubated (volume/volume) with borate buffer containing $22 \%$ polyethylene glycol for one night at $4^{\circ} \mathrm{C}$. After centrifugation to discard the $\mathrm{C} 3$ molecules, the supernatant was analyzed by laser nephelometry as described for C3 with the following modifications: the sample diluent was supplemented with $20 \%$ distilled water to allow a reduction of polyethylene glycol to a maximum of $3.5 \%$ in the reaction mixture during immunoprecipitation.

$\mathrm{C} 3 \mathrm{~d} / \mathrm{C} 3$ ratio was used as index of $\mathrm{C} 3$ conversion. C5a (MW 11,000) was determined by enzyme immunoassay Enzygnost C5a, Behring (Hoechst, Brussels, Belgium). Normal range for healthy adults is 0.15 to $0.45 \mu \mathrm{g} / \mathrm{L}$.

$T N F-\alpha$. TNF- $\alpha$ (MW 20,000) was determined by means of an immunoenzymetric assay (enzyme amplified sensitivity immunoassay, Medgenix Diagnostics SA, Fleurus, Belgium) according to the manufacturer's recommendations. It is a solid-phase enzyme-amplified sensitivity immunoassay performed on a microtiter plate, based on the oligoclonal system, in which several monoclonal antibodies directed against distinct epitopes of the intact cytokine are used, thus allowing high sensitivity. The minimal detectable concentration is $3 \mathrm{pg} / \mathrm{ml}$. Normal TNF- $\alpha$ values in healthy adults are lower than $20 \mathrm{pg} / \mathrm{ml}$.

Histamine. Histamine (MW 110) was determined by immunoenzymatic dosage (Immunotech International, Marseille, France) based on competition between sample histamine and histamine-acetylcholine esterase. The specificity was increased through acylation of sample and tracer histamine and by use of monoclonal antibodies against acylated histamine. Normal plasma histamine levels in healthy adults are less than $1000 \mathrm{pg} / \mathrm{ml}$.

Blood elements. Hematocrit values and leukocyte counts were determined by a Coulter counter (Coulter Electronics, Inc., Hialea, Fla.).

Albumin, retinol binding protein, immunoglobulin $G$, and $\alpha_{2}$-macroglobulin. Concentrations of albumin (MW 66,440 ), retinol binding protein (MW 21,200), immunoglobulin G (MW 160,000), and $\alpha_{2}$-macroglobulin (MW 718,000 ) were determined by laser nephelometry and used during CPB as markers of microvascular leakage.

$C$-reactive protein. C-reactive protein was determined by laser nephelometry. Detection limit of the methods is 5 $\mathrm{mg} / \mathrm{L}$.

Statistical analysis. Results are expressed by the mean value \pm standard error of the mean. For intergroup comparison of clinical and of biologic variables at specific sample times, the nonparametric Mann-Whitney U test was used. The Spearman rank correlation coefficient was assessed for correlation of independent parameters and the Fisher exact test for the analysis of contingency tables. $P$ values $<0.05$ were considered significant. 
Table I. Clinical characteristics of patients with and without CLS

\begin{tabular}{lccc}
\hline \multicolumn{1}{c}{ Variables } & $\begin{array}{c}\text { With CLS } \\
(n=13)\end{array}$ & $\begin{array}{c}\text { Without CLS } \\
(n=11)\end{array}$ & $p$ Value \\
\hline Anasarca $(n)$ & 13 & 0 & \\
Pleural effusions $(n)$ & 13 & 0 & \\
Ascites $(n)$ & 7 & 0 & \\
Radiologic index & & & NS \\
$\quad$ Preop. & $1.9 \pm 0.2$ & $1.7 \pm 0.1$ & NS \\
1 hr postop. & $2.0 \pm 0.2$ & $2.0 \pm 0.1$ & 0.08 \\
24 hr postop. & $2.6 \pm 0.4$ & $1.8 \pm 0.1$ & $<0.01$ \\
48 hr postop. & $4.2 \pm 0.8$ & $2.1 \pm 0.3$ & \\
\hline
\end{tabular}

Values as number $(n)$ or mean \pm standard error of the mean. NS, Not significant.

\section{Results}

Clinical results. According to our definition, CLS developed in 13 of the 24 investigated patients. Clinical characteristics and radiologic index, which was significantly higher in patients with CLS on the second postoperative day, are shown in Table I.

In all 24 neonates, echocardiograms and electrocardiograms allowed us to exclude significant postoperative cardiac dysfunction and rhythm disorders. One patient with CLS had clinical and angiographic signs of thrombosis of the right and left superior venae cavae on the fourth postoperative day. This patient died of this complication 3 months after the operation.

Age at operation, preoperative dosage of prostaglandin $E_{1}$, frequency of cardiac catheterization and atrial septostomy as well as delay between this procedure and operation, and frequency of preoperative mechanical ventilation were not significantly different in patients with and without CLS. Duration of CPB, aortic crossclamp time, complete circulatory arrest, and minimal nasopharyngeal temperature and flow rates during $\mathrm{CPB}$ were similar in patients with and without CLS, as was inotropic and vasodilatory support during and immediately after CPB. Fluid balance and urine output during CPB were not significantly different in patients with and without CLS. The volume of fresh frozen plasma but not albumin administered at the end of CPB was greater in patients with CLS $(p=0.08)$. Table II summarizes preoperative and perioperative patient data.

The volume of fresh frozen plasma and albumin administered over the first 3 postoperative days was greater in patients with CLS than in those without CLS. Infusion of albumin and fresh frozen plasma became unnecessary in all patients with or without CLS from the fourth postoperative day on.

Fluid balance over the first 24 hours after the operation was significantly more positive in patients with CLS than in those without, but urine output and serum creatinine concentrations during the first postoperative day were similar in both patient groups. However, transient renal failure developed in two patients with CLS. After the third postoperative day, all patients had a negative fluid balance that averaged $-0.30 \pm 0.60$ and $-0.34 \pm 0.30 \mathrm{ml} / \mathrm{kg}$ per hour in patients with and without CLS, respectively.

Arterial blood pressure and inotropic and vasodilatory support during the first postoperative day were similar in patients with and without CLS, whereas central venous pressure 24 hours after the operation was significantly higher in patients with CLS than in those without.

Aspartate aminotransferase and creatine kinase levels measured 24, 48, and 72 hours after the operation were similar in both patient groups. Oxygenation index during the first postoperative day was identical in both groups. Duration of mechanical ventilation after the operation and duration of stay in the intensive care unit was significantly longer in patients with CLS.

Table III summarizes postoperative clinical data of patients with and without CLS.

\section{Laboratory tests}

Hematocrit values and albumin, retinol binding protein, immunoglobulin $G$, and $\alpha_{2}$-macroglobulin concentrations. The course of hematocrit values before, during, and after CPB was similar in patients with and without CLS. Hematocrit value fell immediately after institution of CPB from normal preoperative values for age $(40.2 \% \pm 1.5 \%$ and $41.2 \% \pm$ $1.0 \%$ [mean \pm standard error of the mean] to $22.7 \%$ $\pm 0.5 \%$ and $23.4 \% \pm 0.9 \%$ ) in patients with and without CLS, respectively. Hematocrit reached normal values again after the end of CPB $(34.1 \% \pm$ $1.7 \%$ and $33.8 \% \pm 1.5 \%$ in patients with and without CLS, respectively).

Albumin concentrations were similar in both patient groups before CPB and fell in all patients after institution of $\mathrm{CPB}$. Albumin concentrations during CPB were lower in patients with CLS than in those without CLS throughout the duration of CPB $(p<$ $0.05)$. After lung reventilation, albumin concentration fell in patients without CLS, reaching low values similar to those of patients with CLS. Fig. 1 shows the course of albumin concentrations before, 
Table II. Preoperative and perioperative data

\begin{tabular}{|c|c|c|c|}
\hline Variables & $\begin{array}{l}\text { With CLS } \\
(n=13)\end{array}$ & $\begin{array}{c}\text { Without CLS } \\
(n=11)\end{array}$ & $p$ Value \\
\hline Age at operation (days) & $7(2-23)$ & $6(3-12)$ & NS \\
\hline Cardiac catheterization $(n)$ & 9 & 7 & NS \\
\hline Delay between cardiac catheterization and operation (days) & $6.1 \pm 1.7$ & $5.6 \pm 1.5$ & NS \\
\hline Preoperative mechanical ventilation $(n)$ & 9 & 4 & NS \\
\hline Duration of preoperative mechanical ventilation $(\mathrm{hr})$ & $96(24-264)$ & $48(48-96)$ & \\
\hline Preoperative $\mathrm{PGE}_{1}$ dosage $(\mu \mathrm{g} / \mathrm{kg} / \mathrm{min})$ & $0.038 \pm 0.01$ & $0.036 \pm 0.01$ & NS \\
\hline Duration of CPB (min) & $55.6 \pm 4.1$ & $50.6 \pm 5.4$ & NS \\
\hline Duration of aortic clamping (min) & $66.0 \pm 2.3$ & $64.9 \pm 9.9$ & NS \\
\hline Duration of CCA (min) & $60.2 \pm 1.4$ & $58.1 \pm 1.5$ & NS \\
\hline Minimal nasopharyngeal temperature $\left({ }^{\circ} \mathrm{C}\right)$ & $15.1 \pm 0.5$ & $14.3 \pm 0.5$ & NS \\
\hline Flow rate 10 minutes after initiation of $\mathrm{CPB}\left(\mathrm{ml} / \mathrm{min} \cdot \mathrm{m}^{2}\right)$ & $2.7 \pm 0.1$ & $2.7 \pm 0.05$ & NS \\
\hline Flow rate after recirculation $\mathrm{CCA}\left(\mathrm{ml} / \mathrm{min} \cdot \mathrm{m}^{2}\right)$ & $1.7 \pm 0.2$ & $1.9 \pm 0.3$ & NS \\
\hline Flow rate when lungs reventilated $\left(\mathrm{ml} / \mathrm{min} \cdot \mathrm{m}^{2}\right)$ & $2.5 \pm 0.1$ & $2.3 \pm 0.3$ & NS \\
\hline SNP dosage during CPB $(\mu \mathrm{g} / \mathrm{kg} / \mathrm{min})$ & $2.0 \pm 0.3$ & $1.7 \pm 0.4$ & NS \\
\hline SNP dosage at the end of CPB $(\mu \mathrm{g} / \mathrm{kg} / \mathrm{min})$ & $1.1 \pm 0.03$ & $1.03 \pm 0.15$ & NS \\
\hline Epinephrine dosage at the end of CPB $(\mu \mathrm{g} / \mathrm{kg} / \mathrm{min})$ & $0.25 \pm 0.03$ & $0.25 \pm 0.06$ & NS \\
\hline Fluid balance during CPB (ml) & $73.3 \pm 22.0$ & $79.5 \pm 19.7$ & NS \\
\hline Diuresis during $\mathrm{CPB}(\mathrm{ml} / \mathrm{kg} / \mathrm{hr})$ & $12.5 \pm 3.0$ & $8.3 \pm 1.9$ & NS \\
\hline FFP transfusion at the end of CPB $(\mathrm{ml} / \mathrm{kg})$ & $12.1 \pm 1.9$ & $6.0 \pm 2.3$ & 0.08 \\
\hline Albumin infusion at the end of CPB $(n)$ & 3 & 4 & NS \\
\hline $\mathrm{ml} / \mathrm{kg}$ & $7.7(7.5-8.8)$ & $8.3(4.3-9.3)$ & \\
\hline
\end{tabular}

$P G E_{1}$, Prostaglandin $\mathrm{E}_{1} ; C P B$, cardiopulmonary bypass; $C C A$, complete circulatory arrest; $S N P$, sodium nitroprusside; FFP, fresh frozen plasma; $N S$, not significant. Values as number $(n)$, mean \pm standard error of the mean, or median (range).

during, and after CPB in patients with and without CLS.

Retinol binding protein, immunoglobulin $\mathrm{G}$, and $\alpha_{2}$-macroglobulin concentrations were similar in both patient groups before CPB. In patients with CLS, albumin, immunoglobulin $\mathrm{G}$, and $\alpha_{2}$-macroglobulin fell 10 minutes after institution of CPB, as compared with prebypass values, to significantly lower relative concentrations than in patients without CLS $(p<0.05)$. Relative retinol binding protein concentrations tended to be lower in patients with CLS, but the difference was not significant $(p<0.1)$. Fig. 2 depicts relative plasma protein concentrations in patients with and without CLS.

Complement fractions. C3 was within the normal range before $\mathrm{CPB}$ in all patients. $\mathrm{C} 3$ reached significantly lower values at institution of CPB in patients with CLS $(p<0.05)$, and this difference persisted up to the end of CPB. After CPB, C3 tended to remain lower in patients with CLS, but the difference was not significant (Fig. 3).

The course of $\mathrm{C} 4$ was comparable with that of $\mathrm{C} 3$ (Fig. 4), whereas $\mathrm{C} 1$ inhibitor levels in patients with and without CLS were not statistically different (Fig. 5).

Before the operation, C3d/C3 averaged $1.8 \pm 0.3$ in patients with CLS and $1.2 \pm 0.1$ in patients without CLS ( $p=$ not significant). After protamine administration, $\mathrm{C} 3 \mathrm{~d} / \mathrm{C} 3$ rose to $2.8 \pm 0.3$ and $2.6 \pm$ 0.4 in patients with and without CLS, respectively ( $p=$ not significant). C5a was abnormally elevated in all patients before the operation; $\mathrm{C} 5 \mathrm{a}$ values at this time were higher in patients with CLS (C5a, $3.0 \pm 0.6 \mu \mathrm{g} / \mathrm{L}$ ) than in patients without CLS (C5a, $0.9 \pm 0.2 \mu \mathrm{g} / \mathrm{L})(p<0.05)$. However, there was no longer a difference between patients with and without CLS during and after CPB.

Preoperative $\mathrm{C} 5 \mathrm{a}$ values correlated with cumulative fluid balance over the first 24 postoperative hours (Spearman, 0.47, $p<0.05$ ), with radiologic index on the first and second postoperative days (Spearman, 0.70 and 0.47 , respectively, $p<0.05$ ), and with duration of mechanical ventilation after the operation (Spearman, 0.67, $p<0.05$ ). Preoperative C5a was not significantly different in patients who were or were not treated by mechanical ventilation before the operation.

$T N F-\alpha$. TNF- $\alpha$ was similar in both patient groups before and during CPB. After protamine administration, patients with CLS had significantly higher TNF- $\alpha$ values than patients without CLS $(p<0.05)$ (Fig. 6). TNF- $\alpha$ tended to remain higher in patients with CLS 4 hours after the operation, but the difference was not significant. TNF- $\alpha$ during and 
Table III. Postoperative clinical data

\begin{tabular}{|c|c|c|c|}
\hline Variables & $\begin{array}{l}\text { With CLS } \\
(n=13)\end{array}$ & $\begin{array}{c}\text { Without CLS } \\
\quad(n=11)\end{array}$ & p Value \\
\hline \multicolumn{4}{|l|}{ Mean blood pressure $(\mathrm{mm} \mathrm{Hg})$} \\
\hline 4 hr postop. & $61 \pm 2.8$ & $59 \pm 1.9$ & NS \\
\hline 24 hr postop. & $52 \pm 1.7$ & $54.5 \pm 1.7$ & NS \\
\hline \multicolumn{4}{|l|}{ Central venous pressure $(\mathrm{mm} \mathbf{H g}$ ) } \\
\hline $4 \mathrm{hr}$ postop. & $5.7 \pm 0.3$ & $4.7 \pm 0.6$ & NS \\
\hline $24 \mathrm{hr}$ postop. & $7.4 \pm 0.5$ & $5.4 \pm 0.4$ & $<0.05$ \\
\hline \multicolumn{4}{|l|}{ Epinephrine dosage $(\mu \mathrm{g} / \mathrm{kg} / \mathrm{min})$} \\
\hline $4 \mathrm{~h}$ postop. & $0.21 \pm 0.05$ & $0.15 \pm 0.03$ & NS \\
\hline $24 \mathrm{hr}$ postop. & $0.21 \pm 0.1$ & $0.14 \pm 0.08$ & NS \\
\hline \multicolumn{4}{|l|}{ SNP dosage $(\mu \mathrm{g} / \mathrm{kg} / \mathrm{min})$} \\
\hline $4 \mathrm{hr}$ postop. & $1.2 \pm 0.1$ & $1.03 \pm 0.11$ & NS \\
\hline $24 \mathrm{hr}$ postop. & $1.2 \pm 0.08$ & $1.0 \pm 0.15$ & NS \\
\hline Cumulative FFP and HAlb substitution over the 3 first postop. days $(\mathrm{ml} / \mathrm{kg}$ ) & $94.2 \pm 11.3$ & $65.6 \pm 16.4$ & 0.075 \\
\hline Fluid intake $24 \mathrm{hr}$ postop. ( $\mathrm{ml} / \mathrm{kg} /$ hour) & $4.5 \pm 0.4$ & $2.5 \pm 0.3$ & $<0.005$ \\
\hline Renal insufficiency $(n)$ & 2 & 0 & \\
\hline Maximal creatinine value & $69.1 \pm 11.0$ & $52.9 \pm 2.6$ & NS \\
\hline \multicolumn{4}{|l|}{$\mathrm{PaO}_{2} / \mathrm{FiO}_{2}$} \\
\hline $4 \mathrm{hr}$ postop. & $204 \pm 30$ & $242 \pm 40$ & NS \\
\hline 24 hr postop. & $203 \pm 31$ & $245 \pm 37$ & NS \\
\hline Duration of mechanical ventilation (hr) & $139 \pm 15^{*}$ & $68 \pm 6$ & $<0.005$ \\
\hline Maximal aspartate aminotransferace concentration (IU/L) & $61 \pm 24$ & $33 \pm 3$ & NS \\
\hline Maximal creatinekinase concentration (IU/L) & $400 \pm 108$ & $286 \pm 19$ & NS \\
\hline Duration of stay in intensive care unit (days) & $9.5 \pm 1.6^{*}$ & $5 \pm 0.5$ & $<0.005$ \\
\hline Death $(n)$ & 1 & 0 & NS \\
\hline
\end{tabular}

$S N P$, Sodium nitroprusside; FFP, fresh frozen plasma; $H A l b$, human albumin. Values as number $(n)$ or mean \pm standard error of the mean. $*_{n}=12$ (patient who died excluded).

after CPB in both groups did not correlate with the duration of $\mathrm{CPB}$, aortic crossclamp time, or complete circulatory arrest.

Histamine. Histamine release during CPB (histamine concentration after protamine administration - histamine concentration at institution of CPB) was significantly higher in patients with CLS $(724 \pm 396 \mathrm{pg} / \mathrm{ml})$ than in patients without CLS $(-50 \pm 58 \mathrm{pg} / \mathrm{ml})(p<0.05)$.

Leukocytes and differentiation. Before the operation, leukocyte count was significantly higher in patients with CLS $\left(17.9 \pm 2.1 \times 10^{3}\right.$ cells $\left./ \mathrm{ml}\right)$ than in those without $\left(11.7 \pm 0.8 \times 10^{3}\right.$ cells $\left./ \mathrm{ml}\right)(p<0.05)$. During and after CPB, leukocyte counts were similar in both patient groups (data not shown). Preoperative leukocyte count correlated with cumulative fluid balance over the first 24 postoperative hours (Spearman, 0.50, $p<0.05$ ) and with the radiologic index calculated on the second postoperative day (Spearman, 0.45, $p<0.05$ ).

$C$-reactive protein. Eight patients with and seven patients without CLS had preoperatively detectable C-reactive protein values ( $p=$ not significant). Among these patients, $\mathrm{C}$-reactive protein averaged $19.0 \pm 5.0 \mathrm{mg} / \mathrm{L}$ in patients with CLS and $6.8 \pm 0.6$ $\mathrm{mg} / \mathrm{L}$ in patients without CLS ( $p=$ not significant). $C$-reactive protein measured on the first, second, and third postoperative days averaged $29.3 \pm 3.5$ $\mathrm{mg} / \mathrm{L}, 40.5 \pm 6.5 \mathrm{mg} / \mathrm{L}$, and $25.2 \pm 4.8 \mathrm{mg} / \mathrm{L}$, respectively, and was similarly elevated in both patient groups.

\section{Discussion}

Our results demonstrate that neonates undergoing the arterial switch operation for transposition of the great arteries in whom postoperative CLS developed had, in contrast to patients without this complication, increased protein leakage from the intravascular into the extravascular space as early as 10 minutes after initiation of CPB. Inasmuch as the makeup of the priming solution and perioperative course of hematocrit values were strictly similar in both patient groups, more pronounced hemodilution was excluded as a cause of lower protein concentrations in patients with CLS.

In our series, increased microvascular leakage in patients with CLS soon after institution of CPB was observed for proteins with MWs ranging from 21,200 to 718,000 , suggesting that gap formation on the microvascular basement membrane allowed not 


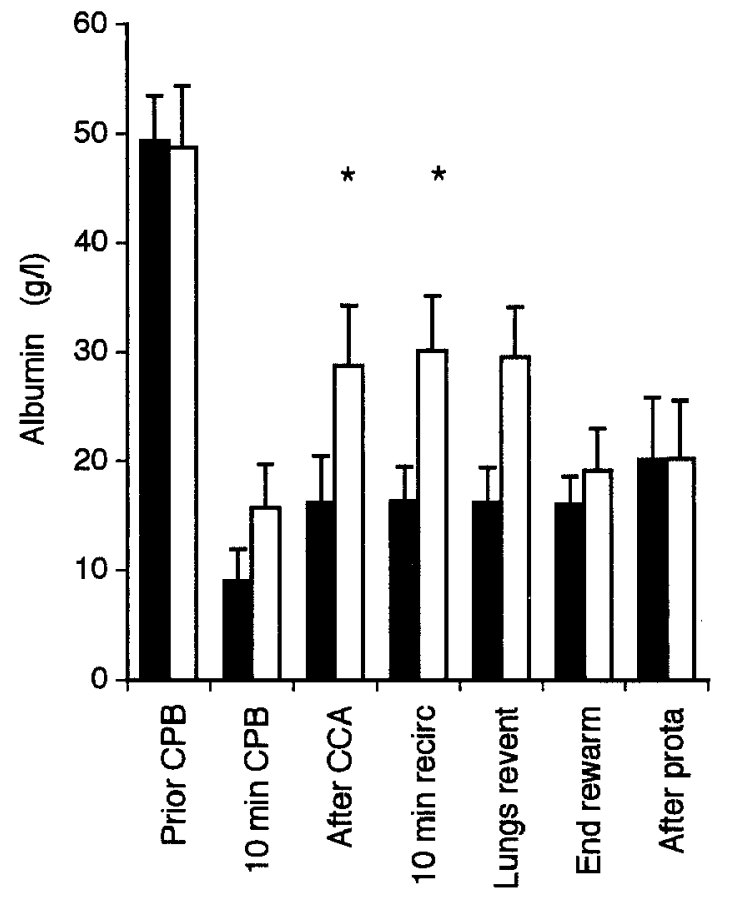

Fig. 1. Course of albumin concentrations before, during, and after $\mathrm{CPB}$ in neonates with (black) and without (white) CLS. *Significant difference between the two groups $(p<0.05) . C C A$, Complete circulatory arrest; recirc, recirculation; revent, reventilation; rewarm, rewarming; prota, protamine.

only small but also macromolecular proteins such as $\alpha_{2}$-macroglobulin to leave the intravascular space, as reported for the idiopathic form of CLS. ${ }^{17}$ Albumin concentrations remained lower in patients with CLS throughout the procedure until lung reventilation, when albumin reached similarly low concentrations in both groups, probably because of the relative overadministration of fresh frozen plasma at this time in patients with CLS.

In our series, patients with CLS had no signs of severe pulmonary edema as shown by the postoperative ratios of arterial oxygen tension to inspired oxygen concentration measured during the first postoperative day, which were similar to those measured in patients without CLS, as also described in the idiopathic form of CLS. ${ }^{18}$ Nevertheless, patients with CLS needed mechanical ventilation for a longer period. This may be ascribed to decreased thoracic wall compliance caused by anasarca and by pleural effusions, which were present only in this group, according to the definition of CLS. Transient renal failure occurred in two of the 13 patients with

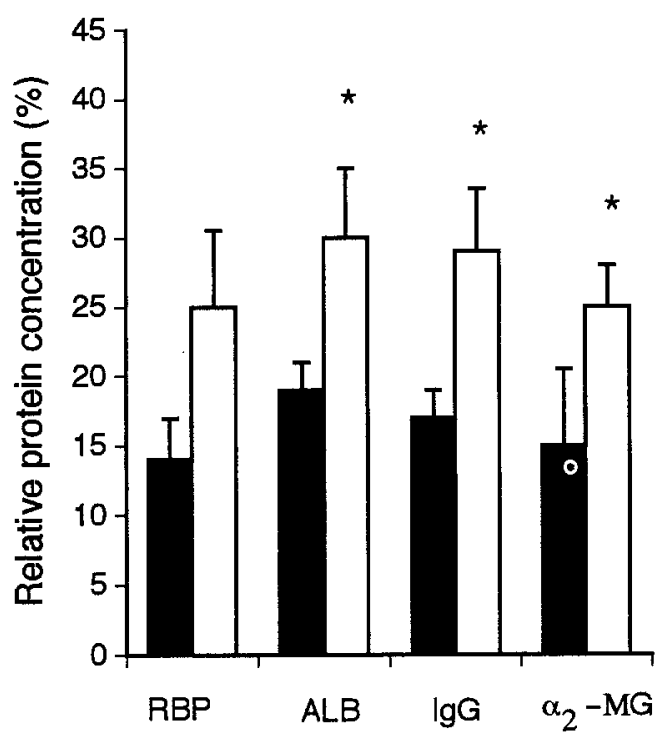

Fig. 2. Relative concentration (expressed as percentage of the prebypass value) of retinol-binding protein $(R B P)$, albumin $(A L B)$, immunoglobulin $\mathrm{G}(\operatorname{Ig} G)$, and $\alpha_{2}$-macroglobulin $\left(\alpha_{2}-M G\right) 10$ minutes after institution of CPB in neonates with (black) and without (white) CLS. *Significant difference between the two groups $(p<0.05)$.

CLS and in none without, suggesting impaired renal perfusion caused by glomerular capillary damage or hypovolemia (or both) in patients with CLS. Indeed, over the first postoperative days, patients with CLS required higher volume administration but not increased inotropic support for hemodynamic stabilization than did patients without CLS.

Higher central venous pressure on the first postoperative day in patients with CLS could be the result of increased pulmonary vascular resistance and could have in turn maintained fluid shift from the intravascular into the extravascular space during the postoperative period. ${ }^{19}$ Arterial vasodilators during and after CPB, which were administered in the same dosage in both patient groups, are in our series unlikely to have influenced the development of CLS, in contrast to experimental results in dogs. ${ }^{19}$ In one patient with CLS, thrombosis of the right and left superior venae cavae developed, which certainly contributed to the persistence of generalized edema by impairing lymphatic return.

CPB induces production and liberation of inflammatory mediators that have the capability to increase microvascular permeability., ${ }^{4,5}$ Among these mediators, TNF- $\alpha$ (which is mainly produced by activated monocytes and macrophage ${ }^{20}$ ) and hista- 


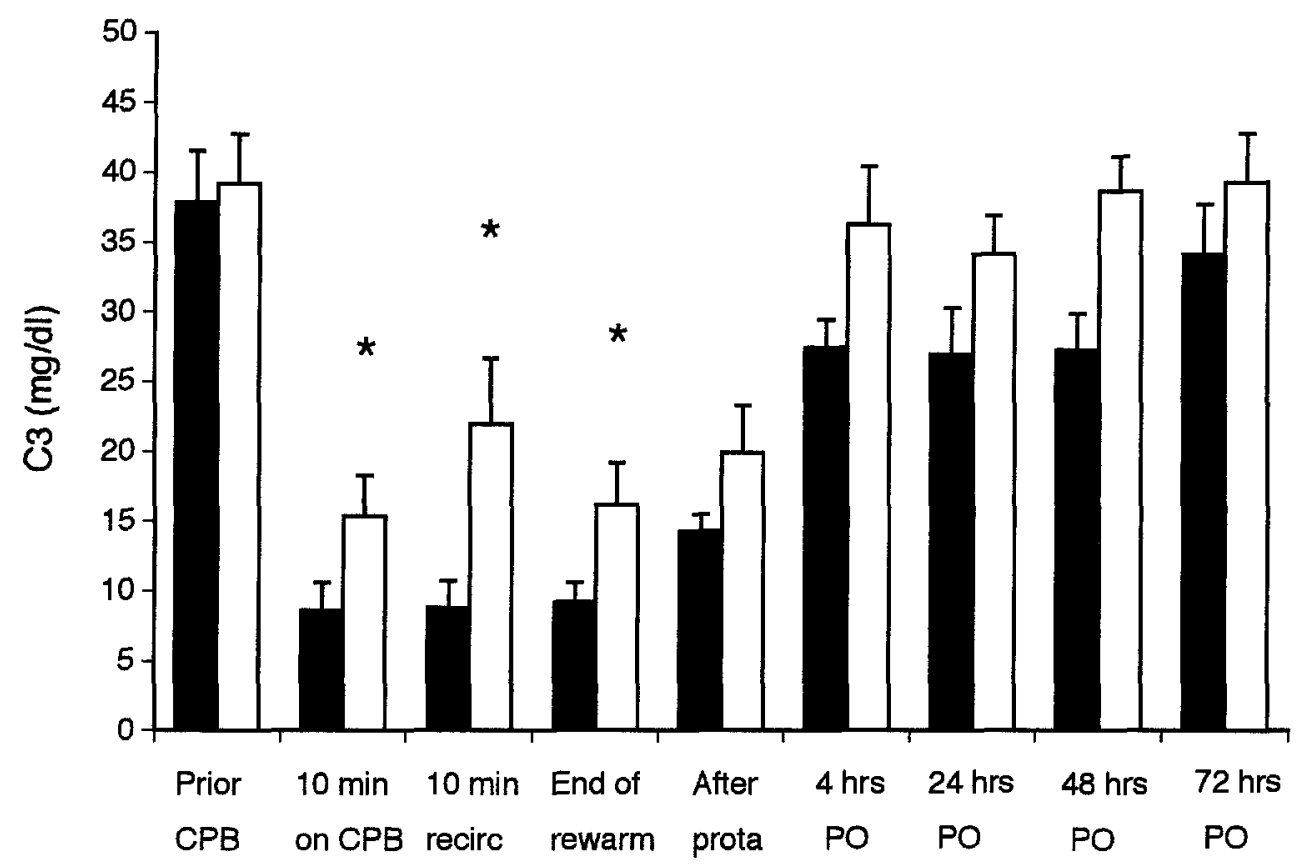

Fig. 3. Course of $\mathrm{C} 3$ before, during, and after $\mathrm{CPB}$ in neonates with (black) and without (white) CLS. Abbreviations as in Fig. 1. PO, Postoperatively. ${ }^{*}$ Significant difference between the two groups $(p<0.05)$.

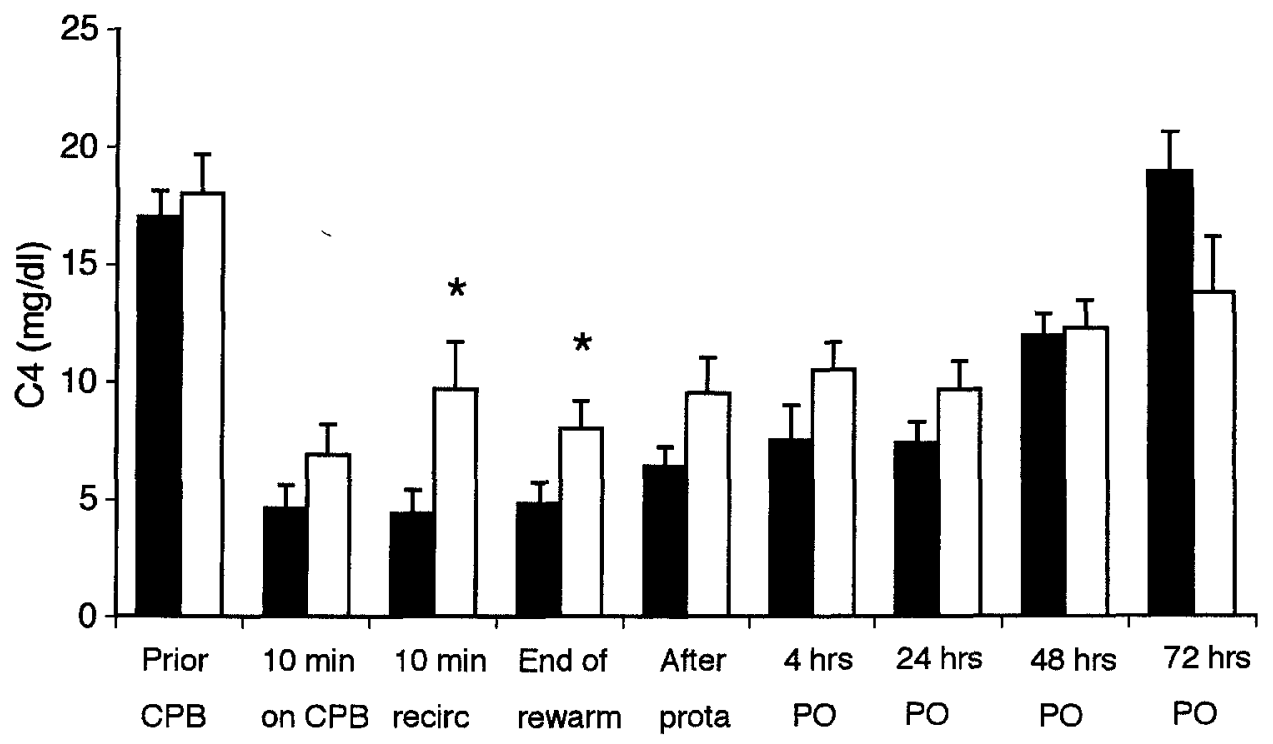

Fig. 4. Course of $\mathrm{C} 4$ before, during, and after CPB in neonates with (black) and without (white) CLS. Abbreviations as in Fig. 1. PO, Postoperatively. *Significant difference between the two groups $(p<0.05)$.

mine (which is principally released from activated basophils in the setting of $\mathrm{CPB}^{6}$ ) are recognized to play a major role in increased microvascular permeability. The exact mechanism underlying microvascular damage by these mediators is not fully under- stood, but it could involve loss of the negative charges of the endothelial monolayer of postcapillary venules, causing endothelial cell contraction and gap formation. ${ }^{8}$ Increased microvascular permeability caused by cytokines and acute agonists of 


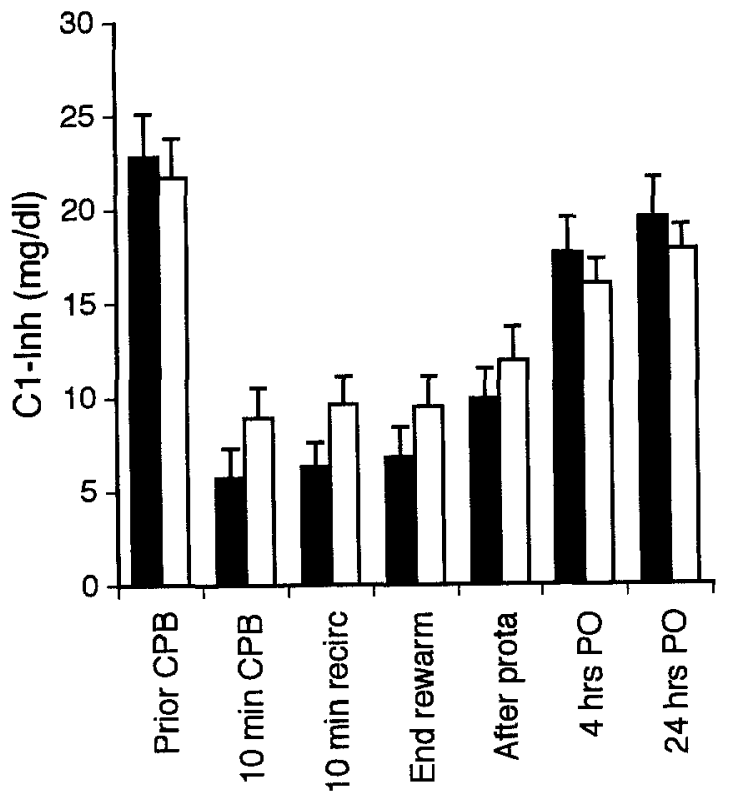

Fig. 5. Course of $\mathrm{C} 1$ inhibitor (C1-inh) before, during, and after $\mathrm{CPB}$ in neonates with (black) and without (white) CLS. Abbreviations as in Fig. 1. PO, Postoperatively.

inflammation occurs either directly or via neutrophil activation and oxygen-derived free radical release. ${ }^{8}$ By inducing expression of cell surface adhesion molecules, TNF- $\alpha$ is thought to play an important role in leukocyte-endothelium interactions and in oxidant release from adherent neutrophils, causing increased microvascular permeability and tissue damage. ${ }^{21}$ Cytokines and acute agonists of inflammation have recently been demonstrated to act synergistically in vitro, ${ }^{9,22}$ this effect allowing the reduction of TNF- $\alpha$ concentrations for the induction of similar changes of the endothelial monolayer permeability.

In our series, higher histamine liberation during $\mathrm{CPB}$ and higher TNF- $\alpha$ synthesis in patients with CLS suggest that in neonates undergoing cardiac operations, these inflammatory mediators could be responsible, at least in part, for increased microvascular permeability. However, at the time when higher protein leakage was already measured in patients with CLS (namely, 10 minutes after induction of CPB), none of the measured mediators could yet be detected in significantly higher concentrations. The reason for this discrepancy might be that in patients with CLS histamine and TNF- $\alpha$, together with other plasma proteins, left the intravascular space.

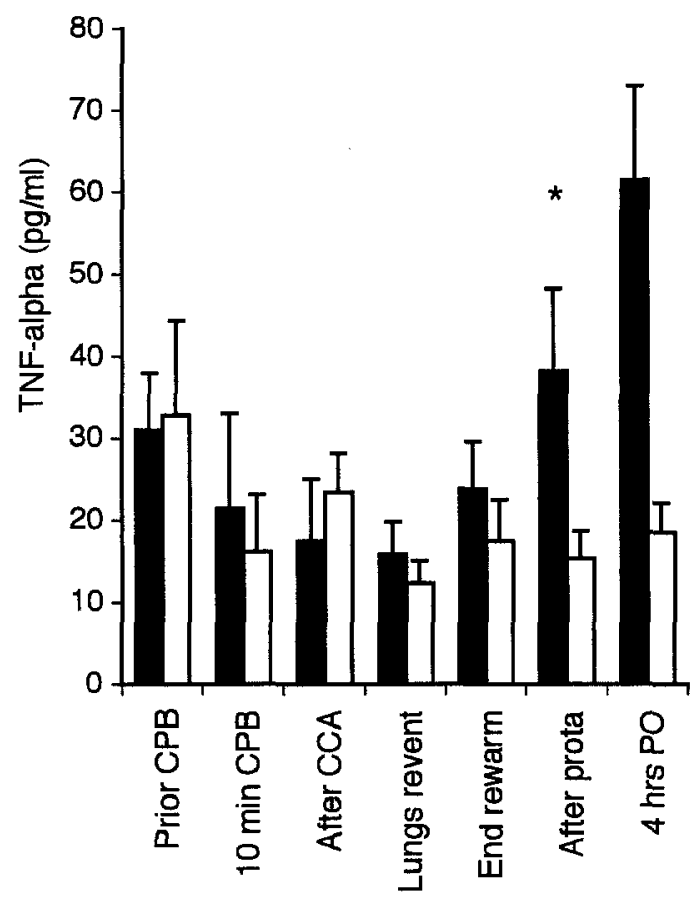

Fig. 6. Course of TNF- $\alpha$ before, during, and after CPB in neonates with (black) and without (white) capillary leak syndrome. Abbreviations as in Fig. 1. PO, Postoperatively. *Significant difference between the two groups $(p<0.05)$.

In contrast to increased histamine liberation and TNF- $\alpha$ synthesis in patients with CLS, increased complement activation during $\mathrm{CPB}$ was not demonstrable in our series. Indeed, levels of complement proteins $\mathrm{C} 3$ and $\mathrm{C} 4$ during $\mathrm{CPB}$ were significantly lower in patients with CLS than in those without, mimicking the course of proteins of similar size such as immunoglobulin G. Thus, because of increased vascular permeability in patients with CLS, consumption and extravascular leakage of complement proteins cannot be differentiated. Furthermore, increased generation of complement anaphylatoxins also could have been masked, explaining similar C3d/C3 and C5a values measured at the end of CPB in both patient groups. Inasmuch as leukocyte activation was greater in patients with CLS, as shown by higher histamine and TNF- $\alpha$ release, and complement anaphylatoxins play an important role in early cellular stimulation during $\mathrm{CPB}^{23}$ a higher degree of complement activation in patients with CLS cannot be excluded here. Leukocyte counts during and after CPB were similar in both patient groups, indicating similar cellular traffic, probably caused by similar circulating amounts of chemoattractant substances such as $\mathrm{C} 5 \mathrm{a} .{ }^{24}$ 
In accordance with reports on idiopathic CLS where normal values of both antigenic and functional $\mathrm{C} 1$ inhibitor are described, ${ }^{25} \mathrm{C} 1$ inhibitor levels during and after CPB in our series were not significantly different in patients with and without CLS. This contrasts, however, with low $\mathrm{C} 1$ inhibitor levels measured in patients with sepsis-related $\mathrm{CLS},{ }^{26}$ suggesting that in the setting of $\mathrm{CPB}, \mathrm{C} 1$ inhibitor deficiency does not play a dominant physiopathologic role.

In our series, patients who had CLS before the operation displayed significantly higher C5a levels and leukocyte counts than patients who did not have CLS. Even though the C-reactive protein concentration was not significantly different, this indicates a preoperative inflammatory state in patients having CLS that was independent of bacterial infection and preoperative management, including prostaglandin $\mathrm{E}_{1}$ regimen, cardiac catheterization, and preoperative mechanical ventilation. This is in accordance with our previous report showing abnormal preoperative complement activation in some but not all neonates undergoing cardiac operations. ${ }^{7}$ The cause of this preoperative inflammatory state remains to be clarified. In our series it could have enhanced the CPB-related inflammatory reaction by cellular priming of inflammatory mediators ${ }^{27}$ and might be the clue for the early increased microvascular injury that we observed in neonates in whom CLS developed. This contention is supported by the correlation observed in our series between preoperative C5a levels and leukocyte count and postoperative radiologic index and fluid balance.

In conclusion, our results show that neonates with clinical signs of CLS after cardiac operations have higher preoperative circulating levels of complement anaphylatoxin $\mathrm{C} 5 \mathrm{a}$ and higher leukocyte counts, indicating a preoperative inflammatory state, than do neonates without this complication. Neonates with CLS also have higher CPB-related liberation of histamine and TNF- $\alpha$ release (both mediators of increased microvascular permeability) and show extravascular protein leakage as early as 10 minutes after initiation of CPB. A preoperative inflammatory state in neonates having CLS could enhance the inflammatory response to $\mathrm{CPB}$ and thereby perioperative capillary damage.

We thank Isa Sprangers, Henri Collet, and Henri Schreyen for technical assistance and Karen Buro for statistical advice.

\section{REFERENCES}

1. Kirklin JK, Westaby S, Blackstone EH, Kirklin JW, Chenoweth DE, Pacifico AD. Complement and the damaging effects of cardiopulmonary bypass. J Thorac Cardiovasc Surg $1983 ; 86: 845-57$.

2. Moat NE, Shore DF, Evans TW. Organ dysfunction and cardiopulmonary bypass: the role of complement and complement regulatory proteins. Eur J Cardiothorac Surg 1993; 7:563-73.

3. Butler J, Rocker GM, Westaby S. Inflammatory response to cardiopulmonary bypass. Ann Thorac Surg 1993;55:552-9.

4. Downing SW, Edmunds LH Jr. Release of vasoactive substances during cardiopulmonary bypass. Ann Thorac Surg 1992:54:1236-43.

5. Seghaye MC, Duchateau J, Bruniaux J, Demontoux S, Bosson $C$, Serraf $A$, et al. Interleukin 10 release related to cardiopulmonary bypass in infants undergoing cardiac operations. J Thorac Cardiovasc Surg 1996;111:545-53.

6. Seghaye MC, Duchateau J, Grabitz RG, Mertes J, Marcus C, Buro K, et al. Histamine liberation related to cardiopulmonary bypass in children: possible relation to transient postoperative arrhythmias. J Thorac Cardiovasc Surg 1996;111:97181.

7. Seghaye MC, Duchateau J, Grabitz RG, Nitsch G, Marcus C, Messmer B, et al. Complement, leukocytes, and leukocyte elastase in full-term neonates undergoing cardiac operation. J Thorac Cardiovasc Surg 1994;108:29-36.

8. Brain SD. Introduction: the microcirculation. In: Brain SD, editor. Immunopharmacology of the microcirculation. London: Academic Press, 1994:1-7.

9. Beynon HLC, Haskard DO, Davies KA, Haroutunian R, Walport MJ. Combinations of low concentrations of cytokines and acute agonists synergize in increasing the permeability of endothelial monolayers. Clin Exp Immunol 1993; 91:314-9.

10. Burch M, Lum L, Eliott M, et al. Influence of cardiopulmonary bypass on water balance hormones in children. Br Heart J 1992;68:309-12.

11. Westendorp RGJ, Draijer R, Meinders AE, van Hinsbergh VWM. Cyclic-GMP-mediated decrease in permeability of human umbilical and pulmonary artery endothelial cell monolayers. J Vasc Res 1994;31:42-51.

12. Brans YW, Dweck HS, Harris HB, Parr GV, Bailey PE, Kirklin JW, et al. Effect of open-heart surgery on the body composition of infants and young children. Pediatr Res 1981;15:1024-8.

13. Beattie HW, Evans G, Garnett ES, Regoeczi E, Webber CE, Wong KL. Albumin and water fluxes during cardiopulmonary bypass. J Thorac Cardiovasc Surg 1974;67:926-31.

14. Simpson J, Stephenson T. Regulation of extracellular fluid volume in neonates. Early Hum Dev 1993;34:179-90.

15. Maehara T, Novak I, Wyse RKH, Eliott MJ. Perioperative monitoring of total body water by bio-electrical impedance in children undergoing open-heart surgery. Eur J Cardiothorac Surg 1991;5:258-65.

16. Check IJ, Pieper M, Papadea C. Immunoglobulin quantitation. In: Rose NR, de Macario EC, Fahey JL, Friedman H, Penn GM, editors. Manual of clinical laboratory immunology. Washington, DC: American Society of Microbiology, 1992:71-83

17. Atkinson JP, Waldmann TA, Stein SF, et al. Systemic capillary leak syndrome and monoclonal IgG gammopathy: 
studies in a sixth patient and a review of the literature. Medicine 1977;56:225-39.

18. George C, Regnier B, Le Gall JR, et al. Hypovolaemic shock with oedema due to increased capillary permeability. Intens Care Med 1978;4:159-63.

19. Wolfer RS, Bishop GG, Burdett MG, Shigemi K, Freeman JP, Krasna MJ, et al. Extravascular fluid uptake during cardiopulmonary bypass in hypertensive dogs. Ann Thorac Surg 1994;57:974-80.

20. Strieter RM, Kunkel SL, Bone RC. Role of tumor necrosis factor- $\alpha$ in disease states and inflammation. Crit Care Med 1993;21:S447-63.

21. Casey LC. Role of cytokines in systemic capillary leak syndrome. In: Aggarwal BB, Puri RK, editors. Human cytokines: their role in disease and therapy. Cambridge (MA): Blackwell Science, 1995:601-7.

22. Burke-Gaffney A, Keenan AK. Modulation of human endo- thelial cell permeability by combinations of the cytokines interleukin- $1 \mathrm{a} / \mathrm{b}$, tumor necrosis factor- $\alpha$ and interferon- $\gamma$. Immunopharmacology 1993;25:1-9.

23. Kalfin RE, Engelman RM, Rousou JA, Flack JE III, Deaton DW, Kreutzer DL, et al. Induction of interleukin- 8 expression during cardiopulmonary bypass. Circulation 1993;88: 401-6.

24. Law SKA, Reid KBM. Activation and control of the complement system. In: Male D, Rickwood D, editors. Complement. Oxford: IRL Press, 1988:9-27.

25. Teelucksingh S, Padfield PL. Systemic capillary leak syndrome. Lancet 1989;1:330-1.

26. Nürnberger W, Göbel U, Stannigel H, Eisele B, Janssen A, Delvos U. C1-inhibitor concentrate for sepsis-related capillary leak syndrome. Lancet 1992;339:990.

27. Baumann $\mathrm{H}$, Gauldie J. The acute phase response. Immunol Today 1994;15:74-80. 